\title{
RENAL HISTOPATHOLOGICAL FINDINGS IN DOGS WITH VISCERAL LEISHMANIASIS
}

\author{
Rosangela Silva RIGO(1), Cristiano Marcelo Espínola CARVALHO(2), Michael Robin HONER(2), Gisele Braziliano de ANDRADE(2), \\ Iandara Shetter SILVA(1), Leonardo RIGO(3), Helen Rezende FIGUEIREDO(4) \& Wanessa Teixeira Gomes BARRETO(5)
}

\begin{abstract}
SUMMARY
Visceral leishmaniasis affects various organs including the kidneys; which can lead to renal failure and death. In order to verify this renal involvement, material was evaluated from 100 dogs naturally infected and with serological diagnosis of canine visceral leishmaniasis (CVL). Inflammatory changes were present in $25.3 \%$ of the tubules, in $67.0 \%$ of interstitium and in $52.0 \%$ of glomeruli. There was no significant difference $(p>0.05)$ between the presence of glomerulonephritis in symptomatic and oligosymptomatic dogs. The membranous and membranoproliferative glomerulonephritis were the most frequent, both with $18.0 \%$ frequency, followed by focal segmental glomerulosclerosis with $14.0 \%$. Changes such as cylindruria, tubular and fibrosis hypertrophy, periglomerular inflammatory infiltrate, and multifocal and diffuse peritubular inflammatory infiltrate were observed. The findings are consistent with those of other authors indicating that renal involvement is common in CVL and the standards of membranous and membranoploriferative glomerulonephritis, as well as the tubulointerstitial involvement, are frequent.
\end{abstract}

KEYWORDS: Renal histopathology; Visceral leishmaniasis; Dogs.

\section{INTRODUCTION}

The numerous species of Leishmania are geographically defined, with a high prevalence in regions of Latin America, Southern Europe and the Middle East. There are three forms of clinical manifestation of the disease: cutaneous, mucocutaneous and visceral.

Brazilian leishmaniasis became urbanized in the 90s, with the dog as the main component in the cycle of human transmission; the disease then became greatly important to public health ${ }^{4}$. Since it develops the disease in a similar manner to man, the dog can serve as model for human studies ${ }^{9}$.

Renal involvement is common as the cause of renal failure and death ${ }^{15,18}$. Renal involvement is very common in dogs with canine visceral leishmaniasis (CVL) due to the deposition of immunocomplexes in the basal membranes of the renal parenchyma. This is caused by persistent infection associated with prolonged antigenemy ${ }^{17}$. Symptomatic and asymptomatic dogs can have varying degrees of renal lesions ${ }^{17}$, as some studies have shown that nearly $100 \%$ of dogs with CVL have macro- or microscopic renal lesions ${ }^{9,18}$. Clinical signs of renal dysfunction, however, only appear with extensive tissue injury ${ }^{7}$. Canine visceral leishmaniasis is usually associated with hyperimmunoglobulinemia with high IgG levels, circulating immune complexes and high titers of rheumatoid factor and cryoglobulin. Together with the presence of immunoglobulins in the glomeruli, this suggests the pivotal role of polyclonal B-cell activation and "classical" B-cell activation in the pathogenesis of leishmanial nephritis ${ }^{27}$.

The objective of this study was to demonstrate renal lesions caused by this parasitic infection. Histopathological studies were carried out with renal tissue of dogs naturally infected by Leishmania (L.) chagasi, obtained from the Zoonosis Control Center in the city of Campo Grande, MS, Brazil, in July and August 2010.

\section{MATERIAL AND METHODS}

Kidney tissue was obtained from 100 dogs of different breeds, adults of both sexes, positive in ELISA and indirect immunofluorescence (IIF) tests for leishmaniasis, collected at the Zoonosis Control Center in the city of Campo Grande in the state of Mato Grosso do Sul (MS), Brazil, in July and August 2010. The dogs were euthanized with the application of intravenous thiopental $50 \mathrm{mg} / \mathrm{kg}$, following anesthesia with a lethal dose of potassium chloride $(2 \mathrm{mmol} / \mathrm{kg} \text {, flask of } 19.1 \% \mathrm{KCl}: 2.56 \mathrm{mEq} / \mathrm{mL})^{7}$. The material was preserved in $10 \%$ formalin, embedded in paraffin, sliced with a microtome to a thickness of $5 \mu \mathrm{m}$ and stained using the following methods: hematoxylin and eosin for the visualization of nuclear and cytoplasmic alterations, PAS for changes of the glomerular basal membrane, and Masson's trichrome for fibrosis. The slides were evaluated with light microscopy, where the classification of the histopathological findings was made according to the criteria of the World Health Organization ${ }^{6}$ and the Banff classification 1997, updated in $2007^{23}$.

In order to classify and grade the lesions in the renal fragments, those with 10 or more glomeruli, and two or more sections of arteries, were considered adequate. The interstitial areas were evaluated for the presence of fibrosis, tubular atrophy and mononuclear infiltrate, quantifying these alterations relative to the extension of the renal cortex. 


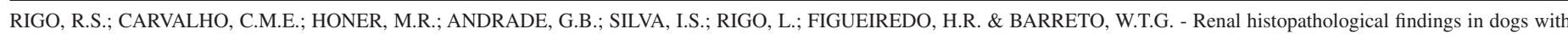
visceral leishmaniasis. Rev. Inst. Med. Trop. Sao Paulo, 55(2): 113-6, 2013.

Weight loss is an important clinical sign that accompanies the evolution of the disease, being part of the clinical diagnosis and used in the classification of the animals for the presence of clinical signs ${ }^{4}$. Since there was no record of weight loss in the records of the animals, their condition at the time of euthanasia was used to classify them into groups: Group \#1 oligosymptomatic, 35 animals, all with good corporal conditions, all being relatively mild and of a form common to leishmaniasis, such as: hyperkeratosis, local alopecia, popliteal lymphadenopathy and opacity of coat. Group \#2 , 65 symptomatic animals with poor corporal conditions, with the signs listed above but more advanced and associated with onychogryphosis, skin ulcers, increased abdominal volume, indicative of hepatomegaly and/or splenomegaly; clinical signs more characteristic of the disease.

Differences between the groups were analyzed by Chi-square and Fishers exact tests for a frequency $(p<5)$.

All procedures were carried out with the approval of the University Ethics Committee, protocol \#74/2008B.

\section{RESULTS}

In $74.7 \%$ of the material evaluated, there was no tubular inflammatory infiltrate, while in $67 \%$ there was some degree of interstitial involvement and in 52\% glomerular lesions were found (Table 1).

\section{Table 1}

Distribution of renal morphological findings, according to Banff classification* in 100 dogs naturally infected with Leishmania sp, Campo Grande, MS, JulyAugust 2010

Qriteria

No tubular mononuclear cells $\%$

Foci with 1-4 mononuclear cells per tubular section

Foci with 5-10 mononuclear cells per tubular section

Foci with $>10$ mononuclear cells per tubular section

Quantitative of interstitial inflammation

No significant inflammation

$10-25 \%$ of cortical interstitial inflammation

$26-50 \%$ of cortical interstitial inflammation

$>50 \%$ of cortical interstitial inflammation

Quantitative of glomerulonephritis

No glomerulonephritis

Glomerulonephritis in up to $25 \%$ of glomeruli

Glomerulonephritis in within $25-75 \%$ of glomeruli

Glomerulonephritis in up to $>75 \%$ of glomeruli

* Banff Classification 97/ Banff 2007 update.

Figure 1 demonstrates the principal glomerulonephritis type encountered. In membranoproliferative glomerulonephritis, an increase in the cells in the glomerular tophus and an increase in the thickness of the basal glomerular membrane were observed, with a characteristic doubled outline. In the case of membranous glomerulonephritis the basal membrane was thickened, without an increase in the cells in the glomerular tophus. In the case of segmental and focal glomerulonephritis, the capillary loops collapsed, present as a partial form within the same

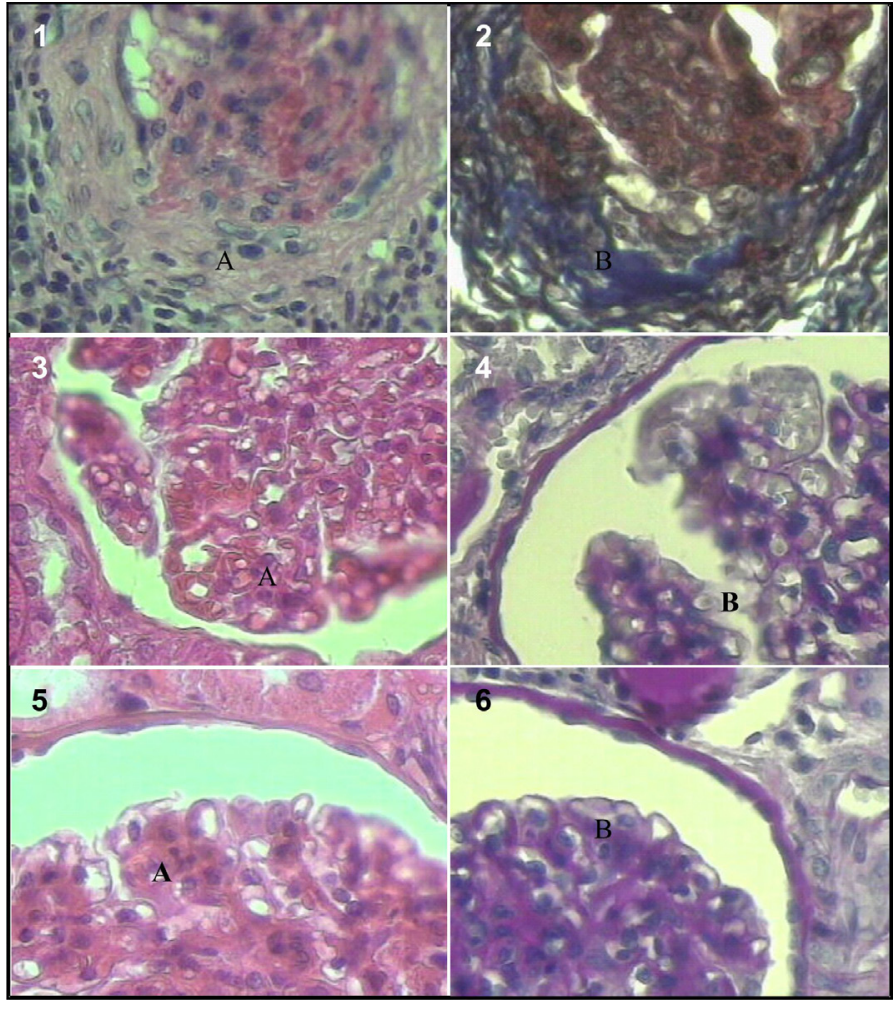

Fig. 1 - 1 and 2 - Segmental and focal glomerulosclerosis - GESF (40x), showing the collapse of the capillary loop, A with HE and B with Masson`s trichrome; 3 and 4 - Membranoproliferative glomerulonephritis - GNMP (40x), thickening of the glomerular basal membrane. 3A - (HE) and 4B - (PAS), hypertrophy of the capillary tuft in 3A; 5 and 6 - Membranous glomerulonephritis- GNMB (10x) showing thickening of the basal glomerular membrane without increase in glomerular cells, A with HE and B with PAS.

glomerulus (segmental) or in only a few glomeruli (focal).

The most frequent types of glomerulonephritis were membranoploriferative glomerulonephritis and membranous glomerulonephritis, $18.0 \%$ respectively (Table 2 ).

In the group of oligosymptomatic dogs, $54.3 \%$ had some degree of glomerular lesions, and in the symptomatic dogs, $50.8 \%$ had no significant difference between the two groups $(p>0.05)$.

When using the histopathological classification of glomerular lesions, there was a significative difference $(p<0.05)$ between the groups; in cases of focal segmental glomerulosclerosis and chronic glomerulonephritis.

Table 3 shows that in the presence of membranous glomerulonephritis there was tubular hypertrophy, isolated or associated with intratubular cylinders, in $50.0 \%$ of the samples; in $16.0 \%$ there was the presence of fibrosis, and in $11.0 \%$ associated of the fibrosis and inflammatory infiltration in the sample. In membranoproliferative glomerulonephritis there was a greater presence of cylinders, isolated or associated with hypertrophy, and inflammatory infiltration, $27.8 \%$ and $22.2 \%$ respectively. In cases of focal segmental glomerulosclerosis there was a $64.3 \%$ incidence of cylinders, isolated or associated with tubular hypertrophy, and fibrosis areas, isolated or associated with inflammatory 
Table 2

Percentage distribution of glomerulonephritis found in dogs naturally infected with Leishmania sp, according to the presence of clinical symptoms, Campo Grande, MS, July-August 2010

\begin{tabular}{|c|c|c|c|}
\hline \multirow[b]{2}{*}{$\begin{array}{l}\text { Classification of } \\
\text { glomerulonephritis }\end{array}$} & \multicolumn{2}{|c|}{ Symptoms Presence } & \multirow[b]{2}{*}{$\begin{array}{c}\text { Total } \\
(\mathrm{n}=100)\end{array}$} \\
\hline & $\begin{array}{c}\text { Oligosympto- } \\
\text { matic } \\
(n=35)\end{array}$ & $\begin{array}{l}\text { Symptomatic } \\
\quad(n=65)\end{array}$ & \\
\hline $\begin{array}{l}\text { Without glomerulone- } \\
\text { phritis }\end{array}$ & 45.7 & 49.2 & 48.0 \\
\hline $\begin{array}{l}\text { Membranous glomerulo- } \\
\text { nephritis }\end{array}$ & 22.9 & 15.4 & 18.0 \\
\hline $\begin{array}{l}\text { Membranoproliferative } \\
\text { glomerulonephritis }\end{array}$ & 22.9 & 15.4 & 18.0 \\
\hline $\begin{array}{l}\text { Focal segmental glome- } \\
\text { rulosclerosis }\end{array}$ & 8.6 & 16.9 & 14.0 \\
\hline $\begin{array}{l}\text { Chronic glomerulone- } \\
\text { phritis }\end{array}$ & 0.0 & 3.1 & 2.0 \\
\hline
\end{tabular}

Table 3

Tubulointerstitials findings, according to the glomerulonephritis found in dogs naturally infected with Leishmania sp, Campo Grande, MS, July-August 2010

\begin{tabular}{lcccc}
\hline & \multicolumn{4}{c}{ \% by glomerulonephritis type } \\
\cline { 2 - 5 } Structure/Injury & $\begin{array}{c}\text { MGN } \\
(\mathrm{n}=18)\end{array}$ & $\begin{array}{c}\text { PMGN } \\
(\mathrm{n}=18)\end{array}$ & $\begin{array}{c}\text { FSGS } \\
(\mathrm{n}=14)\end{array}$ & $\begin{array}{c}\text { Normal } \\
(\mathrm{n}=48)\end{array}$ \\
\hline Tubules & & & & \\
$\quad$ Hypertrophy & 33.3 & 11.1 & 14.3 & 10.4 \\
$\quad$ Cylinders & 5.6 & 22.2 & 14.3 & 22.9 \\
$\quad$ Hypertrophy and cylinders & 16.7 & 5.6 & 50.0 & 25.0 \\
Interstice & & & & \\
$\quad$ Fibrosis & 16.6 & 11.1 & 29.6 & 4.2 \\
$\quad$ Infiltrate & 11.1 & 22.2 & 21.4 & 27.1 \\
$\quad$ Infiltrate and fibrosis & 11.1 & 0.0 & 28.6 & 6.3 \\
\hline
\end{tabular}

MGN: Membranous glomerulonephritis; MPGN: Membranoproliferative glomerulonephritis; FSGS: Focal segmental glomerulosclerosis; Normal: Normal glomeruli.

foci, were observed in $58.2 \%$. Even in the materials of normal glomeruli there was a presence of inflammatory infiltration cylinders in $47.9 \%$ and $33.4 \%$, respectively.

\section{DISCUSSION}

Regardless of the presence of clinical signs, the kidneys are often affected in canine visceral leishmaniasis ${ }^{7}$. TAFURI et al. ${ }^{27}$ stated that the occurrence of glomerulonephritis was considered the principal cause of mortality in VCL - these findings confirm the importance of renal damage in leishmaniasis.

In a study of kidney material from 12 dogs, $91.7 \%$ of interstitial inflammatory alterations and $83.3 \%$ of glomerulosclerosis were seen ${ }^{1}$; rates higher than those found in this study $-24.7 \%$ of interstitial alterations and $31.3 \%$ of glomerular alterations. Histological alterations found in host animals depend on the inflammatory response to the infection, influenced by the ability of the parasite to resist macrophage action and the capacity to inhibit the cellular immune response of the host $\mathrm{t}^{15}$. Histochemical studies are more suitable to confirm these responses, but microscopic observations of the renal tissue studied here, with inflammatory infiltrate in $25.3 \%$ of the samples, suggest the participation of the immunological response in the pathology of the disease.

Lymphocytes from symptomatic dogs proliferated against specific leishmania antigens and asymptomatic dogs can evolve to spontaneous healing, presenting a positive cellular immune response ${ }^{5}$. Canine visceral leishmaniasis is thought to be an immune-mediated disease; where the presence of a humoral response is associated with clinical disease, while the cellular response has been observed in asymptomatic animals ${ }^{1,17}$. A study of dog kidney fragments showed significant differences between membranoproliferative glomerulonephritis and the presence or absence of symptoms ${ }^{24}$. In the present study there was no significant difference between the presence of glomerulonephritis in symptomatic and oligosymptomatic groups, assuming that the renal alterations are more related to immune status and immune cell response of dogs than to the presence of signs and symptoms and exposure time ${ }^{1}$. In visceral leishmaniasis, activation of the immune system occurs and lesions in non-lymphoid organs, including kidneys, occur not only by immune complex deposition, but also through the participation of macrophages, T cells, cytokines and immunoglobulins, by mechanisms which are not yet clear ${ }^{14,27}$.

In the present study the histological pattern was found equal to membranous (18\%) and membranoproliferative glomerulonephritis (18\%), followed by segmental and focal glomerulosclerosis (14\%). An experimental model showed histological alterations from 7-14 days post infection $^{21}$. Since the animals in this study were naturally infected, there was no control over the time of infection, which may influence the degree of the alterations described here. The pattern of membranoproliferative glomerulonephritis was most frequent in studies on renal damage in $\mathrm{CVL}^{2,9,11,25}$. POLI et al..$^{20}$ found $61.8 \%$ of proliferative mesangial focal or diffuse glomerulonephritis in $61.8 \%$ and $35.3 \%$ membranoproliferative in the animals studied. SOARES ${ }^{25}$ found the mesangial proliferative pattern in $64.7 \%$ of asymptomatic dogs, while the symptomatic dogs showed $61.7 \%$ with membranoproliferative glomerulonephritis. A study by BENDERITTER et al. ${ }^{3}$ found $72.7 \%$ with glomerular lesions characterized by acute and membranous glomerulonepthritis. Studies using mice ${ }^{21}$ and hamster ${ }^{22}$ models observed mesangial proliferative glomurolonephritis.

As in this study, others have observed segmental and focal in the second place ${ }^{9,11}$. Studies with dogs naturally and experimentally infected with Leishmania (L.) chagasi found focal or diffuse mesangial glomerulonephritis and proliferation of mesangial cells, interstitial nephritis with heavy infiltration of plasma cells and tubular dilatation ${ }^{26}$. Increased intensity of interstitial inflammatory infiltrate was observed in the cortical and medullary region, mainly in the kidneys of dogs with glomerulonephritis and membranoproliferative glomerulonephritis with minimal alterations ${ }^{13}$.

Alterations such as cylindruria, tubular hypertrophy and fibrosis, as well as periglomerular inflammatory infiltrates and multifocal and diffuse peritubular, were present, as reported in other studies ${ }^{1,9,13}$.

The present study may indicate that renal involvement is common in CVL and that the membranous and membranoproliferative glomerulonephritis 
RIGO, R.S.; CARVALHO, C.M.E.; HONER, M.R.; ANDRADE, G.B.; SILVA, I.S.; RIGO, L.; FIGUEIREDO, H.R. \& BARRETO, W.T.G. - Renal histopathological findings in dogs with visceral leishmaniasis. Rev. Inst. Med. Trop. Sao Paulo, 55(2): 113-6, 2013.

patterns, as well as tubulointerstitial involvement, are frequent. Therefore renal lesions are important factors in the evolution of the disease ${ }^{12}$. Using the dog as a model, this type of lesion should be evaluated in the diagnosis of the disease and taken into consideration in its treatment.

\section{RESUMO}

\section{Achados histopatológicos renais em cães com leishmaniose visceral}

A leishmaniose visceral acomete vários órgãos entre eles os rins; o que pode levar a insuficiência renal e a morte. Com o objetivo de verificar este acometimento renal foram avaliados materiais de 100 cães naturalmente infectados e com diagnósticos sorológicos de leishmaniose visceral canina - LVC. As alterações inflamatórias estavam presentes em $25,3 \%$ dos túbulos, em 67,0\% do interstício e em 52,0\% dos glomérulos. Não houve diferença significativa $(p>0,05)$ entre a presença de glomerulonefrite em cães sintomáticos e oligossintomáticos. As glomerulonefrites membranosa e membrano proliferativa foram as mais freqüentes, ambas com 18,0\% de frequiência seguidas da glomeruloesclerose segmentar e focal com $14,0 \%$. Foram observadas alterações como cilindrúria, hipertrofia tubular e fibrose e infiltrados inflamatórios periglomerulares e peritubulares multifocais e difusos. Os achados concordam com os de outros autores indicando que o acometimento renal é comum na LVC e que os padrões de glomerulonefrites membranoploriferativa e membranosa; assim como o acometimento tubulointersticial são freqüientes.

\section{REFERENCES}

1. Albuquerque BCNC, Maia FCL, Silva Jr VA, Lima AMA, Albuquerque ERC, Pimentel DS, et al. Alterações estruturais em rins de caninos naturalmente infectados por Leishimania (Leishmania) chagasi. Rev Bras Ci Vet. 2008;15:3-5.

2. Barros RM. Caracterização histopatológica da leishmaniose visceral canina no Distrito Federal. [Dissertação]. Brasília:Universidade de Brasília; 2011.

3. Benderitter T, Casanova P, Nashkidachvili L, Quilici M. Glomerulonephritis in dogs with canine leishmaniasis. Ann Trop Med Parasitol. 1988;82:335-41.

4. Brasil. Ministério da Saúde. Secretaria de Vigilância em Saúde. Departamento de Vigilância Epidemiológica. Manual de vigilância e controle da Leishmaniose Visceral. Brasília: Ministério da Saúde; 2003.

5. Campino L, Santos Gomes G, Riça Capela MJ, Cortes S, Abranches P. Infectivity of promastigotes and amastigotes for leishmaniosis. Vet Pathol. 2000;92:269-75.

6. Churg J, Sobin LH, editors. Renal disease: classification and atlas of glomerular diseases. Tokyo: Igaku-Shoin; 1995.

7. Ciaramella P, Oliva G, Luna R, Gradoni L, Ambrosio R, Cortese L, et al. A retrospective clinical study of canine leishmaniasis in 150 dogs naturally infected by Leishmania infantum. Vet Rec. 1997;141:539-43.

8. Conselho Federal de Medicina Veterinária. Brasil. Resolução CFNV nº1000 de 11 de maio de 2012. Dispõe sobre os procedimentos e métodos de eutanásia em animais. Diário Oficial da União. 17 maio 2012; seção 1:124-5. Available from: www.in.gov. br.

9. Costa FA, Goto H, Saldanha LC, Silva SM, Sinhorini IL, Silva TC, et al. Histopathologic patterns of nephropathy in naturally acquired canine visceral leishmaniasis. Vet Pathol. 2003;40:677-84.

10. Costa FA, Guerra JL, Silva SM, Klein RP, Mendonça IL, Goto H. CD4+ T cells participate in the nephropathy of canine visceral leishmaniasis. Braz J Med Biol Res. 2000;33:1455-8.
11. Dias CA. Estudo das alterações clínico-laboratoriais e histopatológicas renais em cães com leishmaniose visceral canina naturalmente infectados no Distrito Federal. [Dissertação]. Brasília: Universidade de Brasília; 2008.

12. Efstratiadis G, Boura E, Giamalis P, Mandala E, Leontsini M, Tsiaousis G, et al. Renal involvement in a patient with visceral leishmaniasis. Nephrol Dial Transplant. 2006;21:235-6.

13. Gomes LA, Goto H, Guerra JLG, Mineiro ALB, Silva SMMS, Costa FAL. Lesões renais intersticiais e tubulares na leishmaniose visceral. Rev Port Ci Vet. 2008;103:157-63.

14. Goto H, Prianti MG. Immunoactivation and immunopathogeny during active visceral leishmaniasis. Rev Inst Med Trop Sao Paulo. 2009;51:241-6.

15. Grimaldi G Jr, Tesh RB. Leishmaniasis of the New World: current concepts and implications for future research. Clin Microbiol Rev. 1993;6:230-50.

16. Lopez R, Lucena R, Novales M, Ginel PJ, Martin E, Molleda M. Circulating immune complexes and renal function in canine leishmaniasis. Zentralbl Veterinarmed B. 1996;43:467-74.

17. Moreno J, Nieto J, Chamizo C, González F, Blanco F, Barker DC, et al. The immune response and PBMC subsets in canine visceral leishmaniasis before, and after, chemotherapy. Vet Immunol Immunopathol. 1999;71:181-95.

18. Moura ROD, De Paula VV, Soares MJV. Alterações renais em cães (Canis familiaris) soropositivos para leishmaniose: aspectos clínicos, laboratoriais e histopatológicos. Rev Bras Med Vet. 2002;4:61-64.

19. Noli C. Leishmaniosis canina. Waltham Focus. 1999;9:16-24.

20. Poli A, Abramo F, Mancianti F, Nigro M, Pieri S, Bionda A. Renal involvement in canine leishmaniasis. A light-microscopic, immunohistochemical, and electronmiscroscopic study. Nephron. 1991;57:444-52.

21. Prianti MG, Yokoo M, Saldanha LC, Costa FA, Goto H. Leishmania (Leishmania) chagasi-infected mice as a model for the study of glomerular lesions in visceral leishmaniasis. Braz J Med Biol Res. 2007;40:819-23.

22. Oliveira AV, Roque-Barreira MC, Sartori A, Campos-Neto A, Rossi MA. Mesangia proliferative glomerulonephritis associated with progressive amyloid deposition in hamsters experimentally infected with Leishmania donovani. Am J Pathol. $1985 ; 120: 256-62$.

23. Sementilli A, David DR, Malheiros D, Visona I, Pegas KL, Franco M, et al. Patologia do transplante renal: achados morfológicos principais e como laudar as biópsias. J Bras Patol Med Lab. 2008;44:293-304.

24. Soares MJV, Moraes JRE, Palmeira Borges V, Miyazato LG, Moraes FR. Renal involvement in visceral leishmaniasis dogs. J Venom Anim Toxins incl Trop Dis. 2005; 11:579-93.

25. Soares MJV. Leishmaniose visceral canina: aspectos clínico-laboratoriais, histopatologia renal e testes específicos para diagnóstico. [Dissertação]. Jaboticabal:Universidade Estadual Paulista; 2003.

26. Tafuri WL, Michalick MS, Dias M, Genaro O, Leite VH, Barbosa AJ, et al. Estudo ao microscópio óptico e eletrônico de rim de cães natural e experimentalmente infectados com Leishmania (Leishmania) chagasi. Rev Inst Med Trop Sao Paulo. $1989 ; 31: 139-45$

27. Tafuri, WL, Oliveira MR, Melo MN, Tafuri WL. Canine visceral leishmaniasis: a remarkable histopathological picture of one case reported from Brazil. Vet Parasitol. 2001;96:203-12.

28. Van Velthuysen MLF, Florquin S. Glomerulopathy associated with parasitic infections Clin Microbiol Rev. 2000;13:55-66.

Received: 5 May 2012

Accepted: 3 September 2012 